\title{
Prevalence of thyroid dysfunction in community of Duwakot, Bhaktapur
}

\author{
Pradhan Binita ${ }^{1}$, Pradhan Sailesh Bahadur ${ }^{2}$

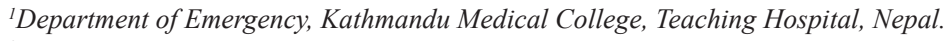 \\ ${ }^{2}$ Department of Pathology, Kathmandu Medical College, Teaching Hospital, Nepal.
}

\section{Keywords:}

Euthyroid;

Hyperthroidism;

Hypothyroidism;

Iodine;

Prevalence;

Thyroid dysfunction

\begin{abstract}
Background: Thyroid dysfunction is one of the major public health problems in the Nepalese community and of the common endocrine disorders diagnosed in community primary health care centres. The aim of this study is to analyze the prevalence of Thyroid dysfunction in Duwakot, Nepal.

Materials and Methods: All the patients from Duwakot community who presented with the history of weight gain with tiredness and weight loss with palpitation were subjected to thyroid function test free triiodothyronine, free thyroxine and thyroid stimulating hormone.

Results: Thyroid dysfunction was found in 26\% with M:F ratio of 1:5. Subclinical hypothyroidism $62(11.44 \%)$ was the most prevalent one followed by Primary hypothyroidism $48(8.85 \%)$, primary hyperthyroidism 16 (2.95\%) and subclinical hyperthyroidism $15(2.76 \%)$.
\end{abstract}

Conclusion: Thyroid dysfuntion has been observed despite of nationwide program regarding supplementation of micronutrient iodised salt.

\section{Correspondence:}

Dr. Binita Pradhan, MBBS, MD

Assistant Hospital Director,

Kathmandu Medical College, Teaching Hospital, Nepal

ORCID ID:0000-0003-4731-1028

Email: binita_pradhan02@yahoo.com

Reveived : June 15th, 2017 ; Accepted : August 2nd, 2017; Published : September 1, 2017

Citation: Pradhan B, Pradhan SB. Prevalence of Thyroid Dysfunction in Community of Duwakot, Bhaktapur. J Pathol Nep. 2017;7:1184-7. DOI: 10.3126/jpn.v7i2.18024

Copyright: This is an open-access article distributed under the terms of the Creative Commons Attribution 4.0 International License, which permits unrestricted use, distribution, and reproduction in any medium, provided the original author and source are credited.

\section{INTRODUCTION}

Thyroid dysfunction is one of the most common disorders, which is diagnosed among the patient seeking medical service in primary health care centers. Altered level of serum thyroid stimulating hormone (TSH) with normal or altered level of thyroid hormones which include free triiodothyronine (fT3) and free thyroxine (fT4) is defined as thyroid dysfunction. ${ }^{1}$

Patients with thyroid dysfunction present with various non-specific symptoms and signs. Most common feature of hypothyroidism is tiredness and weight gain whereas features of hyperthyroidism are palpitation and weight loss. ${ }^{2}$ Thyroid dysfunction increases the risk of osteoporosis, hyperlipidemia, hypercholesterolemia as well 
as cardiovascular and neuropsychiatric disorders. ${ }^{3}$

The micronutrient Iodine deficiency has been found to be the most common cause of thyroid disorders worldwide. ${ }^{4}$ Their manifestations vary considerably from area to area and are determined principally by the availability of iodine in the diet. ${ }^{5}$

Almost one-third of the world's population lives in areas of iodine deficiency. The WHO estimates that two billion people, including 285 million school-age children still have iodine deficiency. ${ }^{5}$

The Nepal Iodine Deficiency Disorders Status Survey (2005) monitoring the effectiveness of iodination program, indicated iodine status sufficiency overall and among rural children, and excess iodine intake among urban children. ${ }^{6}$

The 2016 Nepal Demographic and Health Survey (2016 NDHS) estimated that the vast majority of Nepalese households consume salt with iodine; $95 \%$ of children live in households that consume iodized salt. The percentage of children living in households that use iodized salt is lowest in State $6(82 \%)$, in the Mid-Western region, and in the lowest wealth quintile. ${ }^{\text {? }}$

Various studies of thyroid dysfunction epidemiology have been done around the world which shows different results depending on different community including different ethnic group and influence of iodine intake. Studies of prevalence of thyroid dysfunction in Nepal have been done in only some part of the country. It has been found to be one of the major public health problems in the Nepalese community.

Thyroid dysfunction has been found to be the most common endocrine disorders in south western, eastern and central region of Nepal. ${ }^{1,8-12}$ In this post-iodinization era, the evaluation of thyroid dysfunction prevalence frequency needs to be studied as there are various evolving risk factors. Regular screening program has to be carried out for early recognition and proper management of thyroid dysfunction. Thyroid dysfunction can be identified with the thyroid function test and can be planned for the proper management. It helps timely treatment of the disorder and in prevention of consequences of thyroid dysfunction. This study was carried out to find out the prevalence of thyroid dysfunction among the patients from Duwakot community attending Kathmandu Medical College Teaching Hospital, Duwakot, Nepal.

\section{MATERIALS AND METHODS}

This is a hospital based cross-sectional observational study carried out in Duwakot, Nepal, for a period of 1 year from January 2016 to January 2017. All the patients from Duwakot community who presented with the history of weight gain with tiredness and weight loss with palpitation were subjected to thyroid function test which include free triiodothyronine (fT3), free thyroxine (fT4) and thyroid stimulating hormone (TSH). Permission was obtained from the Institutional review committee for the data collection and publication of the study.

The values obtained were co-related for thyroid dysfunction which was categorised as primary hypothyroidism, subclinical hypothyroidism, primary hyperthroidism, subclinical hyperthyroidism and euthyroid. Interpretation of thyroid function test results were done as primary hypothyroidism (low T3, low T4, elevated TSH), subclinical hypothyroidism (normalT3, normal T4, mildly elevated $\mathrm{TSH}$ ), primary hyperthroidism (raised T3, raised T4, low or undetectable TSH), subclinical hyperthyroidism (normal T3, normal T4, low or undetectable TSH) and euthyroid (normal T3, normal T4, normal TSH). Data were analysed using Microsoft Excel.

\section{RESULTS}

Total numbers of patients attending KMC Community Hospital were 31,381 during our study period, out of which $542(n=542)$ were screened for TFT. Out of these, $401(74 \%)$ were euthyroid and thyroid dysfunction was seen in 141 (26\%). Out of total screened 542 patients, male patients were $86(16 \%)$ and female patients were $456(84 \%)$ with male to female ratio of 1:5. Among patients of thyroid dysfunction, male patients were $23(16 \%)$ and female patients were $118(84 \%)(\mathrm{M}: \mathrm{F}=1: 5)$

Patients with primary hypothyroidism were 48 (8.85\%), subclinical hypothyroidism 62 (11.44\%), primary hyperthyroidism $16(2.95 \%)$ and subclinical hyperthyroidism $15(2.76 \%)$. Normal TSH value was seen in 104 cases $(74 \%)$, elevated TSH in 28 cases $(20 \%)$ and decreased TSH in 9 cases $(6 \%)$. Patients with Primary hypothyroidism male were $11(23 \%)$ and female were $37(77 \%)$. Subclinical hypothyroidism was seen in $6(10 \%)$ male and 56(90\%) female.

Among the patients with primary hyperthyroidism male were $4(25 \%)$ and female were $12(75 \%)$. Subclinical hyperthyroidism was observed in $2(13 \%)$ male and $13(87 \%)$ female. Hypothyroidism was found more commonly among the age group of 45-54 years, subclinical hypothyroidism ( TSH $>$ ) among 25-34 years, hyperthyroidism among 3544 years \& subclinical hyperthyroidism $(\mathrm{TSH}<$ ) among the age group of 25-44 years. (fig. 1)

\section{DISCUSSION}

Thyroid dysfunction is one of the most common endocrine disorders diagnosed in community primary health care centres in Nepal. It has been major public health problem in the Nepalese community. It is associated with significant 


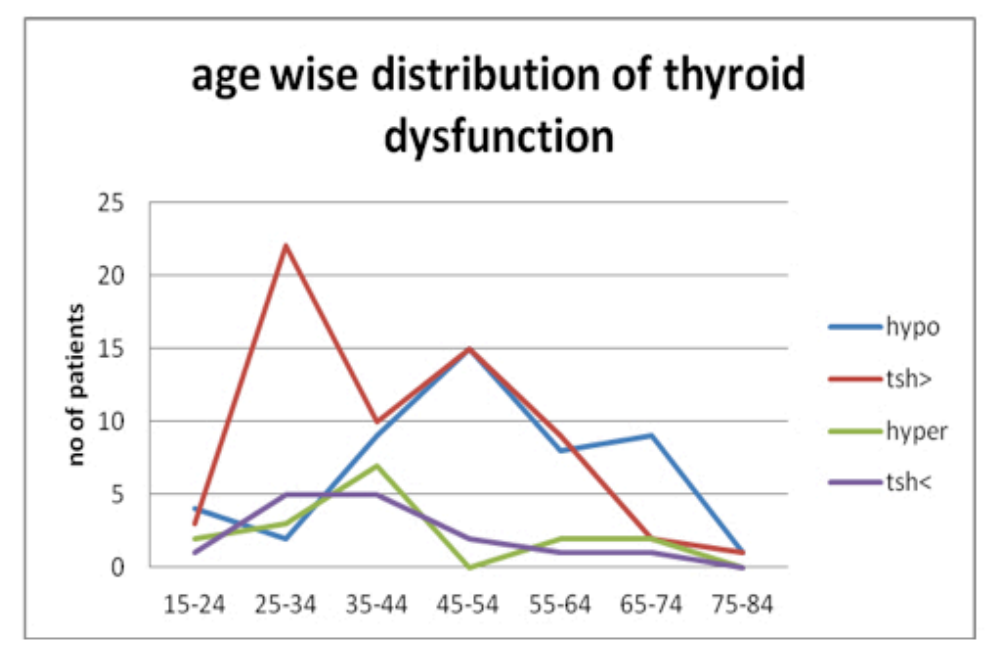

Figure 1: Distribution of thyroid dysfunction according to age.

consequences and usually has non- specific clinical presentation. Thyroid function test has been proven to be highly sensitive and specific in diagnosing thyroid dysfunction.

During our study period the total numbers of community people attending KMC Community Hospital were 31,381. Among those community patients who presented with the signs and symptoms suggestive of thyroid dysfunction screened which comprises 542 cases.

Out of 542 screened patients, 141 (26\%) patients were found to have altered thyroid hormone level. This prevalence pattern is similar to the study done by Aryal $\mathrm{M}$ et $\mathrm{al}^{1}$ and Regmi A et al ${ }^{11}$ which shows $25 \%$ and $25.7 \%$ respectively in the population of central Nepal. Various studies done in different geographical area with different ethnic community in south western, eastern and central region of Nepal have reported high prevalence of thyroid dysfunction. In south western Nepal, prevalence of thyroid dysfunction was $40.37 \% 8$ in eastern Nepal $30.87 \%{ }^{10}$ and in central Nepal $29 \% .^{12}$

Prevalence of thyroid dysfunction varies depending on different communities. Studies done in different part of the world shows different prevalence of thyroid function. A study done in India by Madhuvan HS et $\mathrm{al}^{7}$ and Begum $\mathrm{F}^{13}$ respectively revealed the prevalence of $25 \%$ and $21 \%$ whereas study done in Philippines by Carlos-Raboca $\mathrm{J}$ et $\mathrm{al}^{19}$ shows prevalence of 8.53 percent.

In our study, among the screened patients, male patients comprise $16 \%$ and female patients comprise $84 \%$. The ratio of male to female was $\mathrm{M}: \mathrm{F}=1: 5$. Among patients of thyroid dysfunction, again male patients comprises $16 \%$ and female patients comprises $84 \%$ with the ratio of male female was $\mathrm{M}: \mathrm{F}=1: 5$. The prevalence of thyroid dysfunction was found to be higher in female population. In the studies done in various parts of Nepal by Aryal $\mathrm{M}$ et $\mathrm{al}^{1}$, Rohil $\mathrm{V}$ et $\mathrm{al}^{9}$ and Jayan $\mathrm{A}_{\text {et }} \mathrm{al}^{8}$ showed the percentage of thyroid dysfunction was higher in female. Similarly study done in other Asian countries like Pakistan by Khan A et $\mathrm{al}^{14}$ and study done in India by Madhuvan HS et $\mathrm{al}^{15}$ also concluded with the higher prevalence of female diagnosed with thyroid dysfunction. Even in the study done in US population by Hollowell JG et $\mathrm{al}^{3}$ reported of female predominance with thyroid disorder. The ratio of prevalence of thyroid function has been seen higher in female in all the different national and international community.

In our study primary hypothyroidism were 48 (8.85\%) cases, subclinical hypothyroidism 62 (11.44\%) cases, primary hyperthyroidism $16(2.95 \%)$ cases and subclinical hyperthyroidism $15(2.76 \%)$ cases. Normal TSH was found in 74 with elevated TSH in 20\% (hypothyroidism) and depressed TSH in 6\% (hyperthyroidism). The prevalence of hypothyroidism is higher than hyperthyroidism.

The various studies done in eastern, western and central Nepal also shows the similar trend of higher prevalence of hypothyroidism among the study population., ${ }^{1,8,10-12}$ International studies also showed the similar result of higher prevalence of hypothyroidism than hyperthyroidism..$^{3,13-18}$

In our study, prevalence of all types of thyroid dysfunction were found to be higher among female than in male. Among patients with primary hypothyroidism, male were $11(23 \%)$ and female were 37 (77\%). Among patients with subclinical hypothyroidism, male were $6(10 \%)$ and female were $56(90 \%)$, with primary hyperthyroidism, male were $4(25 \%)$ and female were $12(75 \%)$ and among subclinical 
hyperthyroidism, male $2(13 \%)$ and female $13(87 \%)$.

Hypothyroidism was found most commonly among the age group of 45-54 years; subclinical hypothyroidism among 25-34 years; hyperthyroidism among 35-44 years and subclinical hyperthyroidism among the age group of 25-44 years.

The findings are different in different studies. The study done by Jha B et $\mathrm{al}^{19}$ showed that hypothyroidism was seen more in the age group of 71-95 years and hyperthyroidism in 15-44years. Another study by Regmi et $\mathrm{al}^{11}$ showed that hypothyroidism was seen more in the age group of 40-60 years and hyperthyroidism in 20-40 years. Aryal M et $\mathrm{al}^{1}$ study showed high number of hypothyroidism among age group of 15-30 years. Prevalence of thyroid dysfunction was seen higher in reproductive age group 21-40 in the study done by Jayan A et al. ${ }^{8}$

\section{CONCLUSION}

Despite of nationwide programs regarding supplementation of micronutrient iodised salt, the prevalence of thyroid dysfunction has been observed higher in different communities of Nepal. The evaluation of thyroid dysfunction in larger population needs to be planned for future research. Proper implementation of screening program could reduce the economic and psychological burden to the individuals caused by the morbidity of thyroid dysfunction.

\section{Conflict of Interest: None}

\section{REFERENCES}

1. Aryal M, Gyawali P, Rajbhandari N, Aryal P, Pandeya DR. A prevalence of thyroid dysfunction in Kathmandu University Hospital, Nepal. Biomedical Research. 2010;21:411-5.

2. Strachan MWJ, Newell-Price J. Endocrine Disease. In: Walker BR, Colledge NR, Ralston SH, Penman ID, editors. Davidson's Principles and practice of Medicine. 22nd ed. Churchill Livingstone Elsevier: UK; 2014. pp733-96.

3. Hollowell JG, Staehling NW, Flanders WD et al. Serum TSH, T4, and thyroid antibodies in the United States population (1988 to 1994): National Health and Nutrition Examination Survey (NHANES III). The Journal of Clinical Endocrinology \& Metabolism. 2002;87:48999. Crossref
4. Vanderpump MPJ. The epidemiology of thyroid disease. British Medical Bulletin. 2011;99:39-51. Crossref

5. Vanderpump MPJ. Epidemiology of thyroid disease and swelling. In: Wass JAH, Diabetes (2 ed.).Oxford University Press. 2011. Crossref

6. Protocol of the Nepal National Micronutrient Survey (NNMS) 2015. 7 January 2015. (Cited 26 July 2004). Crossref

7. Nepal Demographic and Health Survey (2016 NDHS) New ERA. April 2017. (Cited 26 July 2004). Crossref

8. Jayan A, Gautam N, Dubey RK, Neupane Y, Padmavathi P, Jha SK, Sinha AK. Prevalence and impact of thyroid disorders based on TSH level among patients visiting tertiary care hospital of South Western Nepal. Nepal Med Coll J. 2015;17:6-10.

9. Rohil V, Mishra AK, Shrewastwa MK, Mehta KD, Lamsal M, Baral N, Majhi S. Subclinical hypothyroidism in eastern Nepal: A hospital based study. Kathmandu Univ Med J. 2010;8:231-7. Crossref

10. Baral N, Lamsal M, Koner BC, Koirala S. Thyroid dysfunction in eastern Nepal. Southeast Asian J Trop Med Public Health. 2002;33:638-4. Crossref

11. Regmi A, Shah B, Rai BR, Pandeya A. Serum lipid profile in patients with thyroid disorders in central Nepal. Nepal Med Coll J. 2010;12:253-6. Crossref

12. Mahato RV, Jha B, Singh KP, Yadav BK, Shah SK, Lamsal M. Status of thyroid disorders in central Nepal: A tertiary care hospital based study. Int J Appl Sci Biotechnol. 2015;3:119-22. Crossref

13. Carlos-Raboca J, Jimeno C A, Kho S A, Andag-Silva A A, Jasul, Jr.G V, Nicodemus, Jr.N A,. Cunanan E C,. Duante CA. The Philippine Thyroid Diseases Study (PhilTiDeS 1): Prevalence of Thyroid Disorders Among Adults in the Philippines. Journal of the Asean Federation of Endocrine Societies. May 2012; Vol 27 No. 1: 27-33.

14. Begum F. A Hospital based study on Thyroid Dysfunction based on estimation of TSH \& Thyroid Hormones. Sch. J App Med Sci. 2015;3:3096-102.

15. Khan A, Khan MMA, Akhtar S. Thyroid Disorders, Etiology and Prevalence. Journal of Medical Sciences.2002; 2:89-94. Crossref

16. Madariaga AG, Palacios SS, Guillén-Grima F, Galofré JC. The Incidence and Prevalence of Thyroid Dysfunction in Europe: A Meta-Analysis. J Clin Endocrinol Metab. 2014;99:923-31. Crossref

17. Canaris GJ, Manowitz NR, Mayor G, Ridgway EC. The Colorado Thyroid Disease Prevalence Study. Arch Intern Med. 2000;160:52634. Crossref

18. Bjoro T, Holmen J, Kruger O et al. Prevalence of thyroid disease, thyroid dysfunction and thyroid peroxidase antibodies in a large, unselected population. The Health Study of Nord-Trùndelag (HUNT). Eur J Endocrinol. 2000;143:639-47. Crossref

19. Jha B, Gurung C.K, Singh JB, Subedi R.C. A study on thyroid disorders in suspected cases attending Om Hospital and Research Centre during 1996-1998. Journal of the Institute of Medicine. 1999;21:1-200. Crossref 